University of Nebraska - Lincoln

DigitalCommons@University of Nebraska - Lincoln

Faculty Publications from the Harold W. Manter Laboratory of Parasitology

7-1-1984

\title{
Discobothrium caribbensis sp. n., a Lecanicephalidean Cestode from a Yellow-Spotted Stingray, Urolophus jamaicensis, in Jamaica
}

Scott Lyell Gardner

University of Nebraska - Lincoln, slg@unl.edu

Gerald D. Schmidt

University of Northern Colorado

Follow this and additional works at: https://digitalcommons.unl.edu/parasitologyfacpubs

Part of the Parasitology Commons

Gardner, Scott Lyell and Schmidt, Gerald D., "Discobothrium caribbensis sp. n., a Lecanicephalidean Cestode from a Yellow-Spotted Stingray, Urolophus jamaicensis, in Jamaica" (1984). Faculty Publications from the Harold W. Manter Laboratory of Parasitology. 14.

https://digitalcommons.unl.edu/parasitologyfacpubs/14

This Article is brought to you for free and open access by the Parasitology, Harold W. Manter Laboratory of at DigitalCommons@University of Nebraska - Lincoln. It has been accepted for inclusion in Faculty Publications from the Harold W. Manter Laboratory of Parasitology by an authorized administrator of DigitalCommons@University of Nebraska - Lincoln. 


\title{
DISCOBOTHRIUM CARIBBENSIS SP. N., A LECANICEPHALIDEAN CESTODE FROM A YELLOW-SPOTTED STINGRAY, UROLOPHUS JAMAICENSIS, IN JAMAICA
}

\author{
Scott Lyell Gardner and Gerald D. Schmidt \\ Department of Biological Sciences, University of Northern Colorado, Greeley, Colorado 80639
}

ABSTRACT: Discobothrium caribbensis sp. n. (Lecanicephalidea) is described from the spiral valve of the yellowspotted stingray, Urolophus jamaicensis from Jamaica. The new species is the only member of the genus described with four testes. It is most similar in number of testes to D. japonicum Yamaguti, 1934, which has six testes and a myzorhynchus. A myzorhynchus is absent in $D$. caribbensis.

Five specimens of minute cestodes were found in the spiral valve of a yellow-spotted stingray, Urolophus jamaicensis, collected at Discovery Bay, Jamaica. They represent a new species and are described herein. Specimens were relaxed in seawater, fixed in AFA, and stained with Semi-

Received 19 June 1983; revised 18 November 1983; accepted 18 November 1983. chon's carmine. All measurements are in micrometers.

\section{Discobothrium caribbensis sp. $\mathbf{n}$.}

(Figs. 1-3)

Description: With the characters of the genus Discobothrium sensu Dailey et Mudry 1968. Craspedote, apolytic. Number of segments 11 or 12 ; gravid segments not present. Posterior margin of velum with single row of spines. Strobilia $(n=3) 629-883(\bar{x}=$ $746 \pm 128)$ long by $63-96(\bar{x}=87 \pm 6)$ maximum
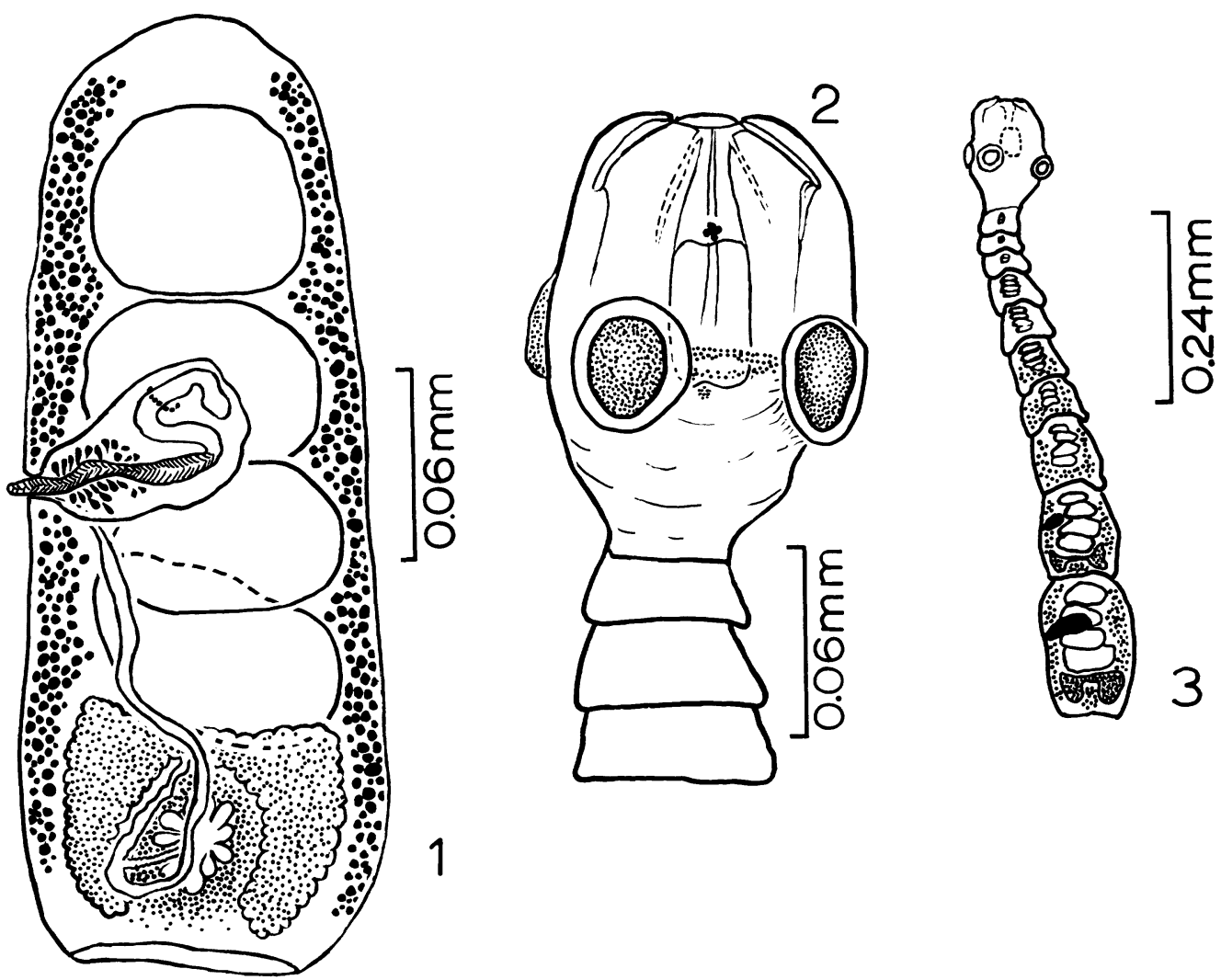

Figures 1-3. Discobothrium caribbensis sp. n. 1. Mature segment. 2. Scolex. 3. Entire worm. 
width in last segment (Fig. 3). Scolex (Fig. 2) length $(n=3)$ 80-91 $(\bar{x}=87 \pm 6)$ by $82-85(\bar{x}=83 \pm 2)$ maximum width. Suckers circular $(n=10) 28-37(\bar{x}=$ $31 \pm 4)$ long by $(n=9) 21-26(\bar{x}=25 \pm 2)$ wide. Scolex covered with minute spines. Myzorhynchus absent. Four testes, each $(n=16) 19-46(\bar{x}=31 \pm 9)$ long, $(n=16) 24-68(\bar{x}=48 \pm 13)$ wide, in one longitudinal row in middle of segment (Fig. 1). Follicular vitellaria extending length of segment in two lateral bands. Ovary (Fig. 1) near posterior end of segment with two lobes connected by anterior isthmus, $(n=4)$ 31-54 ( $\bar{x}=42 \pm 11)$ long, $(n=4) 47-70(\bar{x}=4 \pm 11)$ maximum width. Cirrus spinose. Cirrus sac $(n=4) 22-$ $54(\bar{x}=36 \pm 13)$ long, $(n=4) 24-33(\bar{x}=28 \pm 4)$ wide. Genital pore always unilateral. Genital atrium $(n=3)$ 5-16 $(\bar{x}=10 \pm 5)$ deep, $(n=3)$ 9-10 wide. Terminal segment $(n=4) 146-230(\bar{x}=38 \pm 38)$ long, $(n=4)$ 63-89 $(\bar{x}=83 \pm 14)$ wide.

Type host: Urolophus jamaicensis (Cuvier), yellowspotted stingray.

Location: Spiral valve.

Type locality: Discovery Bay, Jamaica.

Holotype: USNM Helm. Coll. No. 77924.

Paratypes: USNM Helm. Coll. No. 77925.

Etymology: Named for the locality of discovery.

\section{REMARKS}

Dailey and Mudry (1968) noted four valic species of Discobothrium: D. fallax Beneden, 1870, from Raja clavata, Belgium; D. cobraeformis Shipley and Hornell, 1906, from Aetiobatis narinari, Sri Lanka; D. japonicum Yamaguti, 1934, from Narke japonica, Japan; and D. myliobatidis Dailey and Mudry, 1968, from Myliobatis californicus, California, USA. To this list was added D. arrhynchum Brooks, Mayes, and Thorson, 1980, from Myliobatis goodei, Uruguay. Of these, only $D$. japonicum has fewer than 10 testes. That species has six compared with four in $D$. caribbensis. Further, $D$. japonicum has a prominent, stalked myzorhynchus, the ovary is about one-third the distance from the posterior end of the body, and the vitellaria are only as anterior as the posterior testis. Clearly, D. caribbensis represents a previously unknown species.

Discobothrium aegyptiacus Hassen, 1982, is 22 to $38 \mathrm{~mm}$ long, with 230 to 280 segments. We consider it to be a species of Lecanicephalum because of its large size.

\section{LITERATURE CITED}

Brooks, D. R., M. A. MAYes, ANd T. B. Thorson. 1980. Cestode parasites in Myliobatis goodei Garman (Myliobatiformes: Myliobatidae) from Rio de la Plata, Uruguay, with a summary of cestodes collected from South American elasmobranchs during 1975-1979. Proc. Biol. Soc. Wash. 93: 1239-1252.

DaIley, M. D., AND D. R. MudRy. 1968. Two new species of Cestoda from California rays. J. Parasit. 54: 1141-1143.

Hassan, S. W. 1982. Discobothrium aegyptiacus n. sp. a cestode from Raja circularius in the Mediterranean Sea, Egypt. J. Egypt. Soc. Parasitol. 12: 169-173.

Yamaguti, S. 1934. Studies on the helminth fauna of Japan. Part 4. Cestodes of fishes. Jap. J. Zool. 6: $1-112$. 